\title{
Ground and surface water for drinking: a laboratory study on genotoxicity using plant tests
}

\author{
Donatella Feretti, ${ }^{1}$ Elisabetta Ceretti, ${ }^{1}$ Bianca Gustavino, ${ }^{2}$ Ilaria Zerbini, ${ }^{1}$ Claudia Zani, ${ }^{1}$ \\ Silvano Monarca, ${ }^{3}$ Marco Rizzoni ${ }^{2}$ \\ 'Department of Experimental and Applied Medicine, Institute of Hygiene, Epidemiology and \\ Public Health, University of Brescia; ${ }^{2}$ Department of Biology, Tor Vergata University, Rome; \\ ${ }^{3}$ Department of Medical-Surgical Specialities and Public Health, University of Perugia, Italy
}

\begin{abstract}
Significance for public health
The availability of safe drinking water is an important public health problem. Surface waters are increasingly utilized for drinking water because groundwater sources are often polluted by persistent organic pollutants. Several monitoring studies have detected the presence of mutagenic activity in disinfected drinking water, especially from surface sources, due to the reaction of natural organic matter with disinfectant. The choice of the sources as well as the disinfectants for drinking water is one of the most important topics of public health because of chronic exposure to mutagenic compounds. A study model for simulating natural conditions of both deep water and surface water may be a good method for evaluating the genotoxic potential of the products of reaction between humic substances, which are naturally present in surface water, and disinfectants using short-term mutagenicity tests.
\end{abstract}

\footnotetext{
Abstract

Surface waters are increasingly utilized for drinking water because groundwater sources are often polluted. Several monitoring studies have detected the presence of mutagenicity in drinking water, especially from surface sources due to the reaction of natural organic matter with disinfectant. The study aimed to investigate the genotoxic potential of the products of reaction between humic substances, which are naturally present in surface water, and three disinfectants: chlorine dioxide, sodium hypochlorite and peracetic acid. Commercial humic acids dissolved in distilled water at different total organic carbon (TOC) concentrations were studied in order to simulate natural conditions of both ground water $(\mathrm{TOC}=2.5 \mathrm{mg} / \mathrm{L})$ and surface water (TOC=7.5 mg/L). These solutions were treated with the biocides at a 1:1 molar ratio of C:disinfectant and tested for genotoxicity using the anaphase chromosomal aberration and micronucleus tests in Allium cepa, and the Vicia faba and Tradescantia micronucleus tests. The tests were carried out after different times and with different modes of exposure, and at 1:1 and 1:10 dilutions of disinfected and undisinfected humic acid solutions. A genotoxic effect was found for sodium hypochlorite in all plant tests, at both TOCs considered, while chlorine dioxide gave positive results only with the A.cepa tests. Some positive effects were also detected for PAA (A.cepa and Tradescantia). No relevant differences were found in samples with different TOC values. The significant increase in all genotoxicity end-points induced by all tested disinfectants indicates that a genotoxic potential is exerted even in the presence of organic substances at similar concentrations to those frequently present in drinking water.
}

\section{Introduction}

Surface waters are increasingly utilized for drinking water because groundwater sources are often polluted by persistent organic pollutants. Several monitoring studies have detected the presence of mutagenic activity in disinfected drinking water, especially from surface sources, due to the reaction of natural organic matter with disinfectant. Many studies show that natural organic substances (humic and fulvic acids) present in surface waters may react with disinfectants utilized to potabilize waters to produce numerous disinfection by-products (DBPs) that are potentially harmful to human health.

Numerous DBPs have a mutagenic and/or carcinogenic activity, ${ }^{1-4}$ and a large number of DBPs are able to cause cancer in experimental studies. $^{3,5}$ Furthermore, they may play a role in adverse reproductive outcomes such as inability to conceive, spontaneous abortion and low birth weight. ${ }^{6-8}$ Epidemiological studies in populations using chlorinated drinking water obtained from surface sources have shown some cancer hazards. ${ }^{9}$ For this reason, disinfectants such as ozone and chlorine dioxide are used as alternatives to chlorine for water treatment. Humic substances can also react with ozone to produce aldehydes, ketoacids, and carboxylic acids, which contribute to the biodegradable organic carbon content of ozonated water. ${ }^{10}$ Yet aldehydes, formed by ozonation of humic substances (such as formaldehyde, acetaldehyde, glyoxal, glyoxylic acid and methylglyoxal), show a clear mutagenic activity. ${ }^{2-3}$

Humic and fulvic acid concentrations are related to soil and vegetation which are located near water sources, to algae living in water and to seasonal flowering.

Humic compounds are amorphous, brown or black, hydrophilic, acidic, polydispersed substances, with very different molecular weights, and constitute the majority of organic materials present in surface water. ${ }^{11}$ These substances derive from both living and decayed vegetation and microbial decomposition processes. Humic acids are formed by the hetero-polycondensation of carbohydrates, proteins, fatty acids, lignin and many other compounds. They are multifunctional molecules built up by aliphatic carbon skeletons and contain functional groups, including carboxyl, alkoxyl, hydroxyl and carbonyl groups. Their concentration in water is typically quantified in terms of total organic carbon (TOC).

Chlorination of commercial humic acids was proposed as a model for examination of mutagen formation during water chlorination using Salmonella/microsome test. ${ }^{11-13}$ The increasing use of surface water as a source of drinking water may become a public health problem due to the chronic exposure of an elevated number of people to genotoxic compounds. Water genotoxicity can be detected directly by in vivo tests, using aquatic animals, such as amphipods, ${ }^{14}$ fish, newts 
or molluscs ${ }^{15-17}$ or plants, e.g. Zea mays, ${ }^{18}$ Vicia faba,${ }^{19,20}$ Allium cepa ${ }^{21-24}$ and Tradescantia spp. ${ }^{25-29}$

The aim of this study was to investigate the genotoxic potential of the products of reaction between humic substances, which are naturally present in surface waters, and different disinfectants. In order to simulate natural conditions of both deep water $(\mathrm{TOC}=2.5 \mathrm{mg} / \mathrm{L})$ and surface water (TOC=7.5 mg/L), two different concentrations of commercial humic acids were treated with three different disinfectants: two widely used drinking water disinfectants - sodium hypochlorite $(\mathrm{NaClO})$ and chlorine dioxide $\left(\mathrm{ClO}_{2}\right)$ - and peracetic acid $\left(\mathrm{PAA}, \mathrm{CH}_{3}\right.$ $\mathrm{CO}-\mathrm{COOH}$ ), a disinfectant not yet utilized for drinking water. These humic acid solutions were studied using genotoxicity plant tests: the chromosomal aberration test in Allium cepa root cells, and the micronucleus test performed in Tradescantia pollen mother cells and in Allium cepa and Vicia faba root cells (Figure 1).

\section{Materials and Methods}

\section{Sample preparation}

Stock solutions of humic acid (Sigma-Aldrich Corporation, St. Louis, M0, USA) were prepared as follows: two solutions of humic acid, 12.5 $\mathrm{mg} / \mathrm{L}$ and $37.5 \mathrm{mg} / \mathrm{L}$ in distilled water, were stirred for $1 \mathrm{~h}$ at room temperature. Each litre of solution was diluted to 2.5 litres with distilled water and stored overnight at $4^{\circ} \mathrm{C}$. These solutions were prepared to obtain $2.5 \mathrm{mg} / \mathrm{L}$ and $7.5 \mathrm{mg} / \mathrm{L}$ TOC concentrations simulating a ground water and a surface water, respectively (according to Agarwal and Neton, with some modifications). ${ }^{11}$

A solution of commercial sodium hypochlorite (14.65\%) used for drinking water treatment was obtained from Solvay Chimica Italia, S.p.A. (Rosignano, LI, Italy). A chlorine dioxide solution $(0.23 \mathrm{~g} / \mathrm{L})$ was prepared by passing in distilled water a flow of $\mathrm{ClO}_{2}$ produced in a generator provided by Sanipur S.r.l. (Brescia, Italy). A peracetic acid solution containing $15.20 \%$ of PAA in equilibrium with hydrogen peroxide (15.20\%) was used (Promox S.r.l., Leggiuno, VA, Italy). Humic acid solutions with low and high TOC values were treated with 2.5 and 7.5 $\mathrm{mg} / \mathrm{L}$, respectively, of each disinfectant to attain a C:disinfectant molar ratio of 1:1.

The disinfectant residues were monitored in the solutions using colorimetric methods. NaClO concentrations were measured as free dissolved chlorine using a DR 2000 Hach photometer (Hach Company, Loveland, CO, USA) at $530 \mathrm{~nm}$ (Hach 14070/99 method, adapted from Standard Methods, 1998, CI G 4500). $\mathrm{ClO}_{2}$ was determined by the N,Ndiethyl-p-phenylendiamine (DPD) method at $575 \mathrm{~nm}$ (Hach 22423/00 method, adapted from Standard Methods, 1998, CI G 4500). For PAA concentrations, the water was treated with catalase, followed by potassium iodide, and the iodine concentration was measured at $530 \mathrm{~nm}$ (Hach 14064/99 method, adapted from Standard Methods, 1998, CI G 4500). PAA calibration curves were obtained by comparing the DPD absorbance of known concentrations of PAA. The measures were performed using a Hach DR 2000 photometer after every hour, 10 times, to detect the trend of the disinfection process. Another measure was performed $24 \mathrm{~h}$ after the beginning of the treatment. The sample solutions were stored at $4^{\circ} \mathrm{C}$ until the genotoxicity plant tests were carried out.

Sample solutions were used also for AOX (Adsorbable Organic Halogens) analysis using the HPLC method. ${ }^{30}$ AOX value is a measurement used to estimate the total quantity of dissolved halogenated organic material in a water sample. The presence of halogenated organic molecules is indicative of disinfection by-products.

\section{Plant genotoxicity tests}

\section{Allium cepa tests}

In a preliminary assay, equal-sized $(2-2.5 \mathrm{~cm}$ in diameter) young bulbs of Allium cepa were exposed for $72 \mathrm{~h}$ in the dark to undiluted, 1:1 and 1:10 solutions, and root length was measured to determine the EC50 (the concentration which gives a 50\% reduction in root growth). Root length and other macroscopic parameters (turgescence, change in colour, root tip shape) were used as an index of toxicity. ${ }^{22,31}$

Allium cepa Root Anaphase Aberration (AL-RAA) assay and Allium cepa/micronucleus (AL/MCN) test ${ }^{32,33}$ were performed using equalsized young bulbs (2-2.5 $\mathrm{cm}$ in diameter) of Allium cepa. The aberration chromosomal test was carried out at concentrations equal to or lower than the EC50 dose. These samples (undiluted, 1:1 and 1:10 diluted) were tested for 6 - and 24 -h exposures after $72 \mathrm{~h}$ of pre-germination in mineral water. After that, the roots were fixed in 1:3 acetic acidethanol solution for $24 \mathrm{~h}$ and finally stored in $70 \%$ ethanol. One thousand cells/root from 5 roots (5000 cells per sample) were scored for mitotic index and micronuclei, 40 anaphases/root from 20 roots (800 anaphasic cells per sample) were scored for anaphase aberrations, such as bridges, laggards and fragments. Mineral water and two humic acid solutions with different TOC concentration were used as negative controls. A positive control was performed using $10 \mathrm{mg} / \mathrm{L}$ maleic hydrazide to ensure the effectiveness of the assay.

The analysis of variance and Dunnett's t-test were performed for micronuclei, and the chi-square test was performed for data analysis of mitotic index and anaphase aberrations.

\section{Tradescantia micronucleus test}

The Tradescantia micronucleus (Trad/MCN) test was performed using a hybrid of Tradescantia hirsutiflora and Tradescantia subacaulis (clone \#4430). ${ }^{26}$ Young inflorescences of Tradescantia were directly immersed in the samples (only dilutions 1:1 and 1:10 on the basis of the results obtained in Allium cepa preliminary toxicity tests) for $6 \mathrm{~h}$ and then maintained in mineral water for a further $24 \mathrm{~h}$ of recovery time. After that they were fixed in 1:3 acetic acid-ethanol solution and stored in $70 \%$ ethanol. The buds were then used to prepare slides and the micronucleus frequency in meiotic pollen mother cells was evaluated. ${ }^{26}$ Normal tetrads and tetrads containing one or more micronuclei

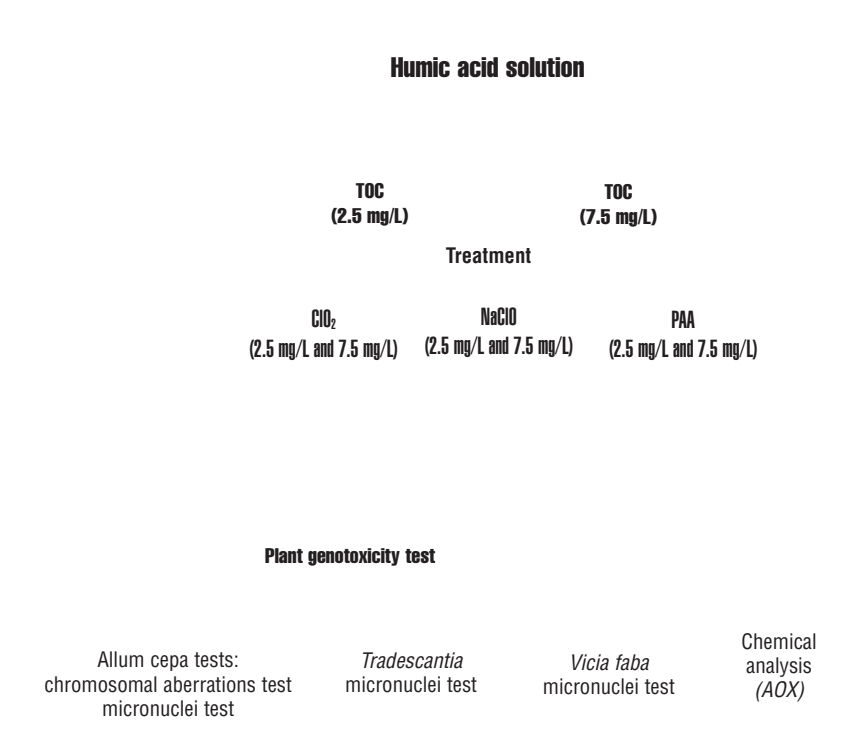

Figure 1. Scheme of the research. 
(MCN) were counted from five slides for each experimental group. Over 1500 tetrads were scored for each sample. The data were expressed as MCN/100 tetrads (mean \pm standard deviation) and analyzed for significance using analysis of variance and Dunnett's t-test. Negative control was carried out using distilled water. Two humic acid solutions with different TOC concentrations were also used as negative controls. A positive control with $5 \mathrm{mg} / \mathrm{L}$ of maleic hydrazide was performed concurrently.

\section{Vicia faba micronucleus test}

Micronucleus test in Vicia faba (Vicia faba/MCN) root tips was performed according to standard protocols. ${ }^{34}$ After germination of Vicia faba seeds in Hoagland's solution, primary roots were removed for a faster secondary root production, which were then exposed in the dark to the treatment solutions (1:10 dilution in Hoagland's solution). Two exposure times were studied: a short interval of $6 \mathrm{~h}$, followed by $66 \mathrm{~h}$ recovery in fresh Hoagland's solution, and $72 \mathrm{~h}$ exposure, until fixation. At the end of treatment, secondary roots were removed and fixed in 1:3 acetic acid-ethanol mixture. Hoagland's salt solution and two humic acid solutions with different TOC concentrations were used as negative controls. Positive control treatment was also performed using maleic hydrazide $10^{-4} \mathrm{M}(11.2 \mathrm{mg} / \mathrm{L})$ in Hoagland's solution (4 h treatment + $44 \mathrm{~h}$ recovery).

Feulgen staining of the roots was performed and the cut tips were squashed onto slides. The mitotic index was estimated on 1000 cells/tip and the frequency of micronuclei was determined in $5 \times 10^{4}$ cells per sample (mean \pm standard error), analysing 5000 cells per root tip, 2 secondary roots per plant, and 5 plants per experimental point (10 root tips/experimental point, $5 \times 10^{4}$ cells/point). Statistical analysis of the data was carried out by means of the Mann-Whitney non-parametric test. The Kruskal-Wallis non-parametric ANOVA was also used for control comparison purposes.

\section{Results}

\section{Chemical analyses}

The results of the chemical analyses for AOX detection carried out on the samples of undiluted humic acids are shown in Figure 2. In the presence of $7.5 \mathrm{mg} / \mathrm{L}$ TOC the AOX values are always higher than $2.5 \mathrm{mg} / \mathrm{L} \mathrm{TOC}$, particularly for $\mathrm{NaClO}$ treatment $(220 \mu \mathrm{g} / \mathrm{L})$. It is noteworthy that the highest AOX values are detected in $\mathrm{NaClO}$ and PAA treated humic acid solutions, at both TOC concentrations.

\section{Plant genotoxicity tests}

\section{Allium cepa tests}

The results of the preliminary toxicity test in Allium cepa carried out on undiluted and diluted (1:1 and 1:10) solutions of humic acid showed very high toxicity in the undiluted solution, therefore the plant genotoxicity tests were performed only at 1:1 and 1:10 diluted humic acid solutions. Exposures to 1:1 and 1:10 humic acid dilutions were carried out for 3,6 and $24 \mathrm{~h}$.

The results of the Allium cepa test on the 1:1 solutions of humic acid are shown in Table 1. Microscopic evaluation of Allium cepa roots was not possible due to the presence of toxicity that hides mutagenic activity in bulbs exposed for $24 \mathrm{~h}$ to the 1:1 dilution; therefore no data are reported for this experimental point. After $3 \mathrm{~h}$ of exposure chromosomal aberrations in Allium root cells were higher compared to the negative control for all samples, the untreated humic acid solutions includ-

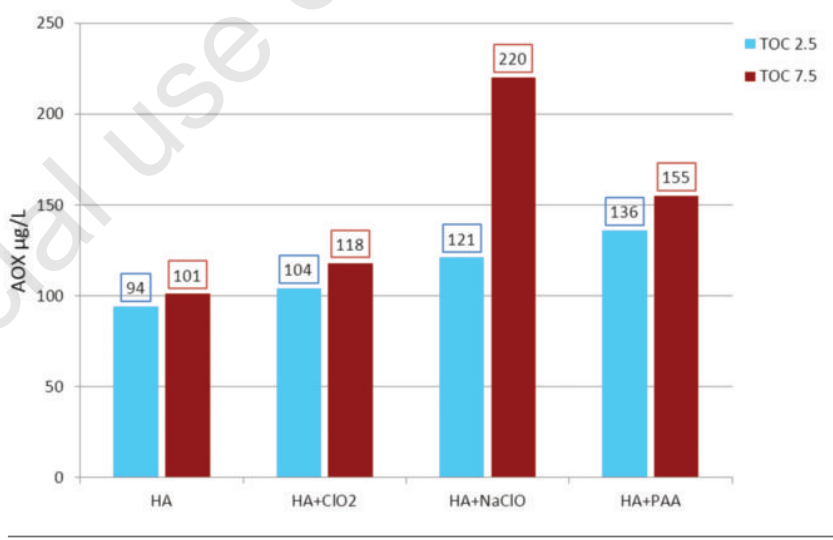

Figure 2. Chemical analyses (AOX) performed on undiluted samples of humic acids (HA) and disinfected humic acids.

Table 1. Mitotic index, anaphase aberrations and micronuclei in Allium cepa root tips exposed for 3 and $6 \mathrm{~h}$ to solutions of treated and untreated humic acids diluted $1: 1$.

\begin{tabular}{|c|c|c|c|c|c|c|}
\hline Samples & $\begin{array}{l}\text { otic index } \\
(\%)\end{array}$ & $\begin{array}{c}1: 1 \text { dilution } \\
3 \text { h exposure time } \\
\text { Anaphase aberrations } \\
(\%)\end{array}$ & $\begin{array}{c}\text { MCN } \\
(\% \text { mean } \pm \text { SD })\end{array}$ & $\begin{array}{c}\text { Mitotic index } \\
(\%)\end{array}$ & $\begin{array}{c}1: 1 \text { dilution } \\
6 \text { h exposure time } \\
\text { Anaphase aberrations } \\
(\%)\end{array}$ & $\begin{array}{c}\text { MCN } \\
(\% \text { mean } \pm \text { SD })\end{array}$ \\
\hline \multirow[t]{2}{*}{ Negative control } & 12.1 & 4.4 & $0.8 \pm 0.8$ & 11.0 & 2.8 & $1.0 \pm 1.2$ \\
\hline & & & \multicolumn{4}{|l|}{ TOC 2.5 mg/L } \\
\hline Humic acids & 9.9 & $8.3^{* *}$ & $1.2 \pm 1.3$ & $7.6^{*}$ & $34.3^{* * *}$ & $2.4 \pm 3.4$ \\
\hline Humic acids $+\mathrm{ClO}_{2}$ & 9.1 & $7.4^{* * *}$ & $1.0 \pm 1.2$ & 8.8 & $49.5^{* * * \circ \circ \circ}$ & $1.6 \pm 1.5$ \\
\hline Humic acids+NaClO & 10.1 & $14.2^{* * * \circ \circ \circ \circ}$ & $0.8 \pm 0.8$ & $8.0^{*}$ & $57.1^{* * * \circ \circ \circ}$ & $6.2 \pm 4.0^{*}$ \\
\hline \multirow[t]{2}{*}{ Humic acids+PAA } & 9.8 & $10.2^{* * *}$ & $0.2 \pm 0.4$ & 8.9 & $68.4^{* * * 000}$ & $3.2 \pm 4.7$ \\
\hline & & & \multicolumn{4}{|l|}{ TOC 7.5 mg/L } \\
\hline Humic acids & 9.5 & $7.2^{*}$ & $0.6 \pm 0.9$ & 10.3 & $42.5^{* * *}$ & $2.8 \pm 0.8^{*}$ \\
\hline Humic acids $+\mathrm{ClO}_{2}$ & 9.3 & $7.5^{* *}$ & $1.2 \pm 1.6$ & 9.3 & $42.2^{* * *}$ & $1.4 \pm 1.1$ \\
\hline Humic acids+ $\mathrm{NaClO}$ & 9.5 & $15.2 * * * \circ 00$ & $1.2 \pm 1.1$ & 9.4 & $50.0^{* * *}$ & $1.6 \pm 1.1$ \\
\hline Humic acids+PAA & 9.8 & $13.8^{* * * 000}$ & $0.8 \pm 1.3$ & 8.1 & $52.0 * * *$ & $1.6 \pm 1.5$ \\
\hline
\end{tabular}

${ }^{*} \mathrm{P}<0.05$ statistically significant vs negative control; $* * \mathrm{P}<0.01$ statistically significant vs negative control; $* * * \mathrm{P}<0.001$ statistically significant vs negative control; ${ }^{\circ 00} \mathrm{P}<0.001$ statistically significant vs humic acid; positive control: maleic hydrazide $(10 \mathrm{mg} / \mathrm{L}) 5.9 \%$ of anaphase aberrations and $7.5 \pm 2.1$ of micronuclei. 
ed. Moreover, $\mathrm{NaClO}$ treatment with $2.5 \mathrm{mg} / \mathrm{L} \mathrm{TOC}$ and $\mathrm{NaClO}$ and PAA treatments with $7.5 \mathrm{mg} / \mathrm{L}$ TOC induced an increase in mutations compared to humic acid without disinfectant. When using a longer exposure time $(6 \mathrm{~h})$, genotoxic damage was much greater but the reduction in mitotic index indicated a strong toxicity, particularly for $2.5 \mathrm{mg} / \mathrm{L}$ TOC samples. For this reason the genotoxicity data may be invalidated. On the other hand, no significant MCN increase is detected from any disinfectant-treated humic acid solution, apart from that induced by $\mathrm{NaClO}$ treatment, but only for humic acid solution with $2.5 \mathrm{mg} / \mathrm{L} \mathrm{TOC}$. In $7.5 \mathrm{mg} / \mathrm{L}$ solution a mild increase in MCN was only seen in humic acid solution without disinfectant.

Actually, a consistent MCN increase is the expected consequence after the dramatic mutagenic effect as that evidenced by the anaphase aberration test. Indeed, the clear cytotoxic effect observed in Allium roots after 3 and $6 \mathrm{~h}$ exposure in all the tested humic acid solutions did not allow cell cycle progression, thereby preventing the production of micronucleated daughter cells. Therefore the Allium test was repeated after 1:10 dilution of all test solutions.

Table 2 shows the results of the Allium cepa test on the 1:10 dilution of humic acid after 6 and $24 \mathrm{~h}$ of exposure. The results showed that all the disinfected samples were positive vs. negative control (undisinfected humic acid solution) after $24 \mathrm{~h}$ of exposure: both humic acid solutions (TOC $2.5 \mathrm{mg} / \mathrm{L}$ and TOC $7.5 \mathrm{mg} / \mathrm{L}$ ) treated with $\mathrm{ClO}_{2}$ induced a significant increase in MCN frequency, whereas NaClO- and PAA-treatments induced anaphase aberrations.

Several samples (disinfected and undisinfected) induced mutations compared to the negative control.

\section{Tradescantia micronucleus test}

The results of the Trad/MCN test are set out in Table 3. Genotoxic effects were found for the solution of humic acid with TOC $2.5 \mathrm{mg} / \mathrm{L}$ treated with $\mathrm{NaClO}$ and PAA after 6-h exposure to dilutions 1:1 and $1: 10$, respectively. The solution with higher TOC disinfected with $\mathrm{NaClO}$ induced a very high level of MCN frequency (dilution 1:1). $\mathrm{ClO}_{2}$ did not induce any genotoxicity in this organism. A slight MCN increase, yet significant at the 1:10 dilution, is registered for untreated humic acid solution with TOC $7.5 \mathrm{mg} / \mathrm{L}$.

\section{Vicia faba micronucleus test}

Mitotic index values ranged from $7.23 \pm 0.85 \%$ to $9.32 \pm 0.28 \%$ (mean \pm standard error) for the treated samples and controls (data not shown). A statistical analysis of these data (Kruskal-Wallis non-parametric ANOVA) indicated no alterations in the proliferating activity of the roots of the controls and treated groups at the same $\mathrm{pH}$ (data not shown).

Significant MCN increases are detected in roots exposed to all the $\mathrm{NaClO}$ treatment solutions compared to both Hoagland solution (negative control) and the corresponding humic acid concentration, at both exposure times. $\mathrm{ClO}_{2}$ also induces a significant micronucleus increase, but only at $6+66 \mathrm{~h}$ of exposure to both solutions (2.5 and 7.5 TOC) (Table 4).

The MCN frequencies observed after $6 \mathrm{~h}$ exposure plus $66 \mathrm{~h}$ recovery time were almost always higher than those detected after $72 \mathrm{~h}$ exposure. Analysis of micronucleus induction in control roots indicated that both humic acid concentrations had no significant effect on Vicia faba micronucleus frequency.

\section{Conclusions}

The aim of this research was to study the formation of genotoxic, and potentially carcinogenic, agents in the products of reaction between commercial humic substances and three disinfectants for drinking water, by means of in vivo short-term plant genotoxicity tests, and to compare the effects of two widely used disinfectants, $\mathrm{ClO}_{2}$ and $\mathrm{NaClO}$, with a new disinfectant, PAA, a potent antimicrobial agent, with many applications in hospitals, laboratories, factories, and wastewater disinfection, but not yet used for drinking water.

All the tested disinfectants induced a clastogenic/aneugenic effect in plant cells, even in the presence of concentrations of organic substances similar to those frequently present in drinking water. All disinfectants determined genotoxic effects in Allium cepa tests. In particular, NaClO- and PAA-treated water samples induced chromosomal aberrations, while $\mathrm{ClO}_{2}$ induced mainly MCN in Allium cepa. Furthermore, $\mathrm{NaClO}$ treatment induced MCN increase in Tradescantia pollen cells and also Vicia faba root cells. Besides, PAA induced MCN in

Table 2. Mitotic index, anaphase aberrations and micronuclei in Allium cepa root tips exposed for 6 and 24 h to solutions of treated and untreated humic acids diluted 1:10.

\begin{tabular}{|c|c|c|c|c|c|c|}
\hline \multicolumn{2}{|c|}{ Mitotic index } & $\begin{array}{c}1: 10 \text { dilution } \\
6 \text { h exposure time } \\
\text { Anaphase aberrations } \\
(\%)\end{array}$ & $\begin{array}{c}\text { MCN } \\
(\% \text { mean } \pm \text { SD })\end{array}$ & $\begin{array}{c}\text { Mitotic index } \\
(\%)\end{array}$ & $\begin{array}{c}1: 10 \text { dilution } \\
24 \mathrm{~h} \text { exposure time } \\
\text { Anaphase aberrations } \\
(\%)\end{array}$ & $\begin{array}{c}\text { MCN } \\
(\% \text { mean } \pm \text { SD })\end{array}$ \\
\hline Negative control & 10.6 & 2.1 & $0.8 \pm 0.8$ & 12.1 & 4.7 & $0.8 \pm 0.8$ \\
\hline \multicolumn{7}{|c|}{ TOC $2.5 \mathrm{mg} / \mathrm{L}$} \\
\hline Humic acids & 8.8 & $5.4^{* * *}$ & $0.4 \pm 0.5$ & 9.5 & 4.7 & $1.2 \pm 1.6$ \\
\hline Humic acids $+\mathrm{ClO}_{2}$ & 10.3 & 2.6 & $0.4 \pm 0.5$ & 10.9 & 4.1 & $6.2 \pm 1.9 * * * \circ \circ \circ$ \\
\hline Humic acids+NaClO & 9.4 & 3.5 & $0.4 \pm 0.5$ & 9.3 & $12.9 * * * \circ \circ \circ$ & $0.2 \pm 0.4$ \\
\hline Humic acids+PAA & 9.3 & $4.4^{* *}$ & $0.2 \pm 0.4$ & $7.8^{* *}$ & $8.9 * * * 000$ & $0.6 \pm 1.3$ \\
\hline \multicolumn{7}{|c|}{ TOC 7.5 mg/L } \\
\hline Humic acids & 10.4 & $3.8^{*}$ & $2.8 \pm 0.8^{*}$ & 10.7 & 4.0 & $1.2 \pm 1.6$ \\
\hline Humic acids $+\mathrm{ClO}_{2}$ & 11.4 & $4.7^{* *}$ & $1.4 \pm 1.1$ & $7.8^{* * \circ}$ & 5.1 & $6.2 \pm 1.9 * * * 000$ \\
\hline Humic acids+NaClO & 8.8 & $4.4^{*}$ & $1.6 \pm 1.1$ & 9.8 & $9.6^{* * * \circ \circ \circ}$ & $0.2 \pm 0.4$ \\
\hline Humic acids+PAA & 8.9 & $5.3^{* * *}$ & $1.6 \pm 1.5$ & $8.0^{\circ \circ}$ & $10.7^{* * * \circ \circ \circ \circ}$ & $0.6 \pm 1.3$ \\
\hline
\end{tabular}

${ }^{*} \mathrm{P}<0.05$ statistically significant vs negative control, ${ }^{*} \mathrm{P}<0.01$ statistically significant vs negative control; ${ }^{* * *} \mathrm{P}<0.001$ statistically significant vs negative control; ${ }^{\circ} \mathrm{P}<0.05$ statistically significant vs humic acid; ${ }^{\circ} \mathrm{P}<0.01$ statistically significant vs humic acid; ${ }^{\circ}{ }^{\circ} \mathrm{P}<0.001$ statistically significant vs humic acid; positive control: maleic hydrazide $(10 \mathrm{mg} / \mathrm{L}) 5.9 \%$ of anaphase aberrations and $7.5 \pm 2.1$ of micronuclei. 
Tradescantia, but only in the presence of a low concentration of TOC $(2.5 \mathrm{mg} / \mathrm{L})$. $\mathrm{NaClO}$ was clearly found to be more genotoxic than PAA and $\mathrm{ClO}_{2}$.

Several studies have shown that treating surface drinking waters with disinfectants such as $\mathrm{NaClO}, \mathrm{ClO}_{2}$ and PAA causes an increase in the mutagenic activity of the treated water, whereas other disinfectant treatments, such as the use of ozone, decreased their mutagenic effects. ${ }^{3,29,35,36}$

In our study all the treatments played an important role in DBP formation, but the concentration of organic substances did not appear to

Table 3. Mean frequency $( \pm S D)$ of micronuclei in early tetrads of Tradescantia inflorescences exposed for $6 \mathrm{~h}$ to solutions of treated and untreated humic acids diluted 1:1 and 1:10.

\begin{tabular}{lcc} 
Samples & $\begin{array}{c}\text { 1:1 dilution } \\
\text { MCN/100 tetrads } \\
(\text { mean } \pm \text { SD })\end{array}$ & $\begin{array}{c}1: 10 \text { dilution } \\
\text { MCN/100 tetrads } \\
\text { (mean } \pm \text { SD })\end{array}$ \\
Negative control & $5.7 \pm 1.3$ & $2.9 \pm 1.3$ \\
Humic acids & $6.5 \pm 1.7$ & \\
Humic acids $+\mathrm{ClO}_{2}$ & $6.4 \pm 2.1$ & $4.7 \pm 0.4$ \\
Humic acids $+\mathrm{NaClO}$ & $8.2 \pm 1.8$ & $5.9 \pm 2.0^{*}$ \\
Humic acids $+\mathrm{PAA}$ & $11.3 \pm 4.1^{* * \circ}$ & $8.4 \pm 1.9^{* * * \circ}$ \\
& TOC $7.5 \mathrm{mg} / \mathrm{L}$ & $5.8 \pm 3.1$ \\
Humic acids & $6.6 \pm 2.7$ & $7.7 \pm 4.6^{*}$ \\
Humic acids $+\mathrm{ClO}_{2}$ & $6.5 \pm 1.9$ & $10.9 \pm 4.5^{* *}$ \\
\hline Humic acids $+\mathrm{NaClO}$ & $20.2 \pm 12.5^{* * \circ}$ & $4.6 \pm 1.7$ \\
Humic acids $+\mathrm{PAA}$ & $11.9 \pm 7.8$ & $6.0 \pm 3.5$ \\
\hline
\end{tabular}

*P $<0.05$ statistically significant vs negative control according to Dunnett's test; $* * \mathrm{P}<0.01$ statistically significant vs negative control according to Dunnett's test; ${ }^{* * *} \mathrm{P}<0.001$ statistically significant vs negative control according to Dunnett's test; ${ }^{\circ} \mathrm{P}<0.05$ statistically significant vs humic acid according to Dunnett's test; positive control: maleic hydrazide $(5 \mathrm{mg} / \mathrm{L}) 15.4 \pm 2.8$ of micronuclei.

Table 4. Mean micronucleus frequencies \pm SE (per 5000 cells) in Vicia faba root tips exposed for 6 and $72 \mathrm{~h}$ to the humic acid solutions (2.5 and 7.5 TOC) alone or treated with the three disinfectants, after dilution 1:10 in Hoagland solution.

\begin{tabular}{|c|c|c|}
\hline Samples & $\begin{array}{r}\mathrm{MCN} / 5 \\
\text { (mea }\end{array}$ & $\begin{array}{l}000 \text { cells } \\
\mathrm{n} \pm \mathrm{SE})\end{array}$ \\
\hline \multicolumn{3}{|l|}{ Negative control: Hoagland solution } \\
\hline \multicolumn{3}{|c|}{$\begin{array}{cc}6 \mathrm{~h} & 72 \mathrm{~h} \\
\text { exposure time exposure time }\end{array}$} \\
\hline \multicolumn{3}{|c|}{ TOC 2.5 mg/L } \\
\hline Humic acids & $2.2 \pm 0.39$ & $1.7 \pm 0.47$ \\
\hline Humic acids $+\mathrm{ClO}_{2}$ & $3.2 \pm 0.49 *$ & $2.5 \pm 0.67$ \\
\hline Humic acids + $\mathrm{NaClO}$ & $4.9 \pm 0.96 * * \circ$ & $3.8 \pm 0.71 * \circ$ \\
\hline Humic acids + PAA & $3.0 \pm 0.60$ & $2.5 \pm 0.62$ \\
\hline \multicolumn{3}{|c|}{ TOC 7.5 mg/L } \\
\hline Humic acids & $3.2 \pm 0.74$ & $1.7 \pm 0.26$ \\
\hline Humic acids $+\mathrm{ClO}_{2}$ & $3.4 \pm 0.43^{*}$ & $3.5 \pm 0.90$ \\
\hline Humic acids + NaClO & $5.3 \pm 0.61^{* * *}$ & $3.5 \pm 0.45^{* \circ \circ}$ \\
\hline Humic acids + PAA & $2.8 \pm 0.51$ & $2.6 \pm 0.52$ \\
\hline
\end{tabular}

${ }^{*} \mathrm{P}<0.05$ statistically significant vs Hoagland solution according to Mann-Whitney test; $* * \mathrm{P}<0.01$ statistically significant vs Hoagland solution according to Mann-Whitney test; ${ }^{* * *} \mathrm{P}<0.001$ statistically significant vs Hoagland solution according to Mann-Whitney test; ${ }^{\circ} \mathrm{P}<0.05$ statistically significant vs humic acid according to Mann-Whitney test; ${ }^{\circ} \mathrm{P}<0.01$ statistically significant vs $1 \mathrm{~mm}$ acid according to MannWhitney test; positive control: maleic hydrazide $(11.2 \mathrm{mg} / \mathrm{L}) 28.5 \pm 6$. influence this; unexpectedly, no relevant differences were found in samples with different values of TOC: highest TOC concentration (7.5 $\mathrm{mg} / \mathrm{L}$ ) did not induce a greater genotoxic effect than $2.5 \mathrm{mg} / \mathrm{L} \mathrm{TOC}$ concentration samples. Also, low TOC concentration, similar to ground water, may react with disinfectants to produce DBPs with mutagenic effects on plant systems. These observations are partially in accordance with data from Gustavino et al. ${ }^{37}$ at least for PAA. Drinking water obtained from surface water sources does not seem to induce a higher increase in mutagenicity than that obtained from ground water.

These experimental conditions suggest that not only surface water rich in organic substances may induce the formation of DBP, and the choice of disinfectant and its dosage are always important.

In the Allium cepa test, exposure time influenced genotoxicity: the longest exposure induced a significant increase in DNA damage in comparison with short exposure. This effect was partially seen in Vicia $f a b a$ as well. When time exposure was extended, toxicity and mutagenicity effects generally increased, but toxicity probably prevented potential genotoxic activity.

In this study the Allium cepa test was certainly more sensitive to the mutagenic effects produced by disinfected humic acid, but even humic acids alone, without disinfectants, were genotoxic in Allium cepa.

The plant tests seem to be suitable for studying the genotoxicity of commercial humic acids treated with different disinfectants, and the solutions of humic acids were a good model for examining DBP formation during water disinfection, regardless of their concentration. The use of plants may allow the detection of intermediary mutagenic metabolites, which can be produced independently of the organic carbon content.

The use of commercial humic acids in aquatic and terrestrial research has been critically reviewed, however. ${ }^{38}$ The authors found large differences in seven samples of commercial humic acids, purchased from different suppliers, in comparison with natural compounds, when they were detected by NMR and IR spectroscopy. Also on the other hand there is much literature in favour of the use of these humic substances as a model for the formation of DBPs. Commercial humic substances for the examination of mutagen formation during water chlorination were used by Li et al. ${ }^{39}$ who studied the effect of $\mathrm{ClO}_{2}$ on DBP formation and found that THMFP could be induced by treatment with mixtures of $\mathrm{ClO}_{2}$ and $\mathrm{Cl}_{2}$ in varying ratios. Different disinfectants can contribute to DPB formation in a different way as a function of humic acid composition, structure and functional properties. Moreover, humic acids can exert an anticlastogenic action in different plants too, ${ }^{40-42}$ and this should clarify the behaviour observed in this study at different TOCs, where an increase in TOC did not cause an increase in mutagenicity. The highest TOC probably contributed to greater DBP formation, but at the same time humic acids reduced their genotoxicity. A protective effect against the toxicity of the chlorinated compounds has been reported in in vivo tests by Gustavino et al. ${ }^{37}$ Therefore, the observed mutagenicity is the result of a soft balance in organic matter concentration in water and disinfectant (type, dose and contact time).

Disinfection remains the fundamental treatment of drinking water because the risks to human health from disinfection by-products are extremely small in comparison with the risks associated with inadequate disinfection, but the chronic exposure of a large number of people to mutagenic and/or carcinogenic compounds imposes the adoption of risk-reduction strategies and measures, such as reducing DPB concentrations, changing the disinfection process, using different chemical disinfectants with a lower propensity to produce by-products with the source water, using non-chemical disinfection processes, removing precursor compounds prior to disinfection process and/or removing DBPs prior to distribution. A study model using disinfected humic acid solutions can provide additional information on DBP formation and may help health authorities to evaluate drinking water quality and 
adopt effective strategies for reducing genotoxic compounds in disinfected drinking water.

In conclusion, in agreement with previous studies, $\mathrm{NaClO}$ in particular, but also $\mathrm{ClO}_{2}$ and PAA, was genotoxic in plants and these tests were useful for evaluating the mutagenicity of different drinking water disinfectants using humic acid solutions as a study model.

\author{
Correspondence: Dr. Donatella Feretti, Dipartimento di Medicina \\ Sperimentale ed Applicata, Sezione di Igiene, Epidemiologia e Sanità \\ Pubblica, Università di Brescia, viale Europa 11,25123 Brescia. \\ Tel. +39.030 .3717691 - Fax: +39.030 .3717688 . \\ E-mail: feretti@med.unibs.it \\ Key words: disinfection by-products, humic acids, mutagenicity, plant assays. \\ Conflict of interest: the authors declare no conflicts of interest. \\ Received for publication: 29 November 2011. \\ Accepted for publication: 23 December 2011 \\ (C) Copyright D. Feretti et al., 2012 \\ Licensee PAGEPress, Italy \\ Journal of Public Health Research 2012; 1:e7 \\ doi:10.4081/jphr.2012.e7 \\ This work is licensed under a Creative Commons Attribution NonCommercial \\ 3.0 License (CC BY-NC 3.0)
}

\section{References}

1. Bull RJ, Reckhowb DA, Li X, et al. Potential carcinogenic hazards of non-regulated disinfection by-products: haloquinones, halocyclopentene and cyclohexene derivatives, $\mathrm{N}$-halamines, halonitriles, and heterocyclic amines. Toxicology 2011;286:1-19.

2. Liviac D, Creus A, Marcos R. DNA damage induction by two halogenated acetaldehydes, byproducts of water disinfection. Water Res 2010;44:2638-46.

3. Richardson SD, Plewa MJ, Wagner ED, et al. Occurrence, genotoxicity, and carcinogenicity of regulated and emerging disinfection by-products in drinking water: a review and roadmap for research. Mutat Res 2007;636:178-242.

4. World Health Organization. Guidelines for drinking-water quality. 3rd ed, Vol 1 Reccomendations. WHO, Geneva, Switzerland, 2004.

5. Boorman GA, Dellarco V, Dunnick JK, et al. Drinking water disinfection byproducts: review and approach to toxicity evaluation. Environ Health Perspect 1999;107:207-17.

6. Aggazzotti G, Righi E, Fantuzzi G, et al. Chlorination by-products (CBPs) in drinking water and adverse pregnancy outcomes in Italy. J Water Health 2004;2:233-47.

7. Klinefelter GR, Suarez JD, Roberts NL, DeAngelo AB. Preliminary screening for the potential of drinking water disinfection byproducts to alter male reproduction. Reprod Toxicol 1995;9:571-8.

8. Legay C, Rodriguez MJ, Serodes JB, Levallois P. Estimation of chlorination by-products presence in drinking water in epidemiological studies on adverse reproductive outcomes: a review. Sci Total Environ 2010;408:456-72.

9. IARC, Monographs on the Evaluation of Carcinogenic Risks to Humans. Some drinking-water disinfectants and contaminants, including arsenic, vol. 84. International Agency for Research on Cancer, Lyon, France, 2004.

10. Singer PC. Humic substances as precursors for potentially harmful disinfection by-products. Water Sci Technol 1999;40:25-30.

11. Agarwal SC, Neton J. Mutagenicity and alkylating activity of the aqueous chlorination products of humic acid and their molecular weight fractions. Sci Total Environ 1989;79:69-83.

12. Kopfler FC, Ringhand HP, Meier JR, Kaylor W. Comparison of mutagenic activity of chlorinated aquatic and commercial humic substances. In: RL Jolley, LW Condie, JD Johnson, S Katz, RA Minear, JS Mattice and VA Jacobs (eds.) Water chlorination chemistry, environmental impact and health effects. Lewis Publ., Chelsea, MI, USA, 1990, pp. 147-158.

13. Venier P, Bonaldo A, Contiero E, et al. Mutagenic activity of chlorinated surface water and humic acid solutions. Int J Environ Health Res 1994;4:17-31.

14. Lacaze E, Devaux A, Jubeaux G, et al. DNA damage in Gammarus fossarum sperm as a biomarker of genotoxic pressure: intrinsic variability and reference level. Sci Total Environ 2011;409:3230-6.

15. Bolognesi C, Hayashi M. Micronucleus assay in aquatic animals. Mutagenesis 2011;26:205-13.

16. Gauthier L, Levi Y, Jaylet A. Evaluation of the clastogenicity of water treated with sodium hypochlorite or monochloramine using a micronucleus test in newt larvae (Pleurodeles waltl). Mutagenesis 1989;4:170-3.

17. Jaylet A, Gauthier L, Fernandez M. Detection of mutagenicity in drinking water using a micronucleus test in newt larvae (Pleurodeles waltl). Mutagenesis 1987;2:211-4.

18. De Marini DM, Plewa M, Brockman HE. Use of four short term tests to evaluate the mutagenicity of municipal water. J Toxicol Environ Health 1982;9:127-40.

19. Minissi S, Caccese D, Passafiume F, et al. Mutagenicity (micronucleus test in Vicia faba root tips), polycyclic aromatic hydrocarbons and heavy metal content of sediments collected in Tiber river and its tributaries within the urban area of Rome. Mutat Res 1998;420:77-84.

20. Rizzoni M, Gustavino B, Ferrari C, et al. An integrated approach to the assessment of the environmental quality of the Tiber river in the urban area of Rome: a mutagenicity assay (micronucleus test) and analysis of macrobenthic community structure. Sci Total Environ 1995;162:127-37.

21. Fiskesjo G. The Allium test as a standard in environmental monitoring. Hereditas $1985 ; 102: 99-112$.

22. Fiskesjo G. The Allium test- a potential standard for the assessment of environmental toxicity. In: JW Gorsuch, FJ Dwyer, CG Ingersoll and TW La Point (eds.) Environmental Toxicology and Risk Assessment, 2nd Volume. American Society for Testing and Materials, Philadelphia, PA, USA, 1993, pp. 331-345.

23. Leme DM, de Franceschi de Angelis D, Marin-Morales MA. Action mechanisms of petroleum hydrocarbons present in waters impacted by an oil spill on the genetic material of Allium cepa roots cells. Aquatic Toxicol 2008; 88:214-219.

24. Matsumoto ST, Mantovani MS, Malaguttii MIA, et al. Genotoxicity and mutagenicity of water contaminated with tannery effluents, as evaluated by the micronucleus test and comet assay using the fish Oreochromis niloticus and chromosome aberrations in onion roottips. Genet Mol Biol 2006;29:148-58.

25. Ma TH, Anderson VA, Harris MM, et al. Mutagenicity of drinking water detected by the Tradescantia micronucleus test. Can J Genet Cytol 1985;27:143-50.

26. Ma TH, Cabrera GL, Chen R, et al. Tradescantia micronucleus bioassay. Mutat Res 1994;310:221-30.

27. Monarca S, Rizzoni M, Gustavino B, et al. Genotoxicity of surface water treated with different disinfectants using in situ plant test. Environ Mol Mutagen 2003;41:353-9.

28. Monarca S, Feretti D, Zani C, et al. Mutagenicity of drinking water disinfectants using plant tests. Environ Mol Mutagen 2005;46:96103.

29. Misík M, Ma TH, Nersesyan A, et al. Micronucleus assays with Tradescantia pollen tetrads: an update. Mutagenesis 2011;26:215 
21.

30. APHA, AWWA, WEF. Standard methods for the examination of water and wastewater, 20th ed., USA, 1998.

31. Rank J, Nielsen MH. Allium cepa anaphase-telophase root tip chromosome aberration assay on N-methyl-N-nitrosourea, maleic hydrazide, sodium azide, and ethyl methanesulfonate. Mutat Res 1997;390:121-7.

32. Rank J, Nielsen MH. Evaluation of the Allium anaphase-telophase test in relation to genotoxicity screening of industrial wastewater. Mutat Res 1994;312:17-24.

33. Ma TH, Xu Z, Xu C, et al. The improved Allium/Vicia root tip micronucleus assay for clastogenicity of environmental pollutants. Mutat Res 1995;334:185-95.

34. Degrassi F, Rizzoni M. Micronucleus test in Vicia faba root tips to detect mutagen damage in fresh-water pollution. Mutat Res 1982;97:19-33.

35. Buschini A, Carboni P, Frigerio S, et al. Genotoxicity and cytotoxicity assessment in lake drinking water produced in a treatment plant. Mutagenesis 2004;19:341-7.

36. Krasner SW. The formation and control of emerging disinfection by-products of health concern. Philos Trans R Soc A 2009;367:4077-
95.

37. Gustavino B, Buschini A, Monfrinotti M, et al. Modulating effects of humic acids on genotoxicity induced by water disinfection in Cyprinus carpio. Mutat Res 2005;587:103-13.

38. Malcom RL, MacCarty P. Limitations in the use of commercial humic acids in water and soil research. Environ Sci Technol 1986; 20:904-11.

39. Li JW, Yu Z, Gao M, et al. Effect of ultraviolet irradiation on the characteristics and trihalomethanes formation potential of humic acid. Water Res 1996;30:347-50.

40. Gichner T, Badaev F, Pospisil F, Veleminsky J. Effects of humic acids, para-aminobenzoic acid and ascorbic acid on the N-nitrosation of the carbamate insecticide propoxur and on the mutagenicity of nitrosopropoxur. Mutat Res 1990;229:37-41.

41. De Marco A, De Simone C, D'Ambrosio C, Owczarek M. Buthionine sulfoximine prevents the reduction of the genotoxic activity of maleic hydrazide by soil humic substances in Vicia faba seedlings. Mutat Res 1999;438:89-95.

42. Ferrara G, Loffredo E, Simeone R, Senesi N. Evaluation of antimutagenic and desmutagenic effects of humic and fulvic acids on root tips of Vicia faba. Environ Toxicol 2000;15:513-7. 